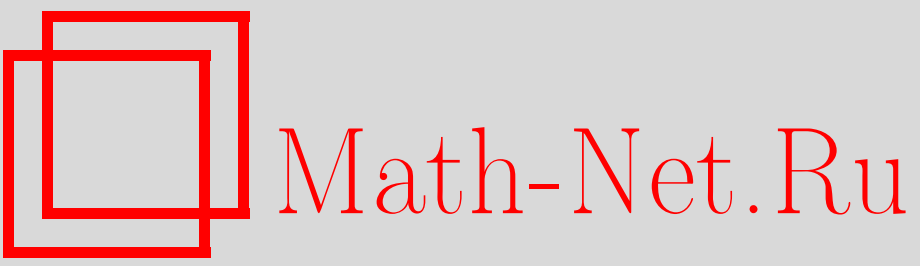

А. А. Барсова, Памяти Ивана Сергеевича Волкова, ректора Куйбышевского политехнического института, Вестн. Сам. гос. техн. ун-та. Сер. Физ.-мат. науки, 2011, выпуск 4(), 13-17

DOI: https://doi.org/10.14498/vsgtu1034

Использование Общероссийского математического портала Math-Net.Ru подразумевает, что вы прочитали и согласны с пользовательским соглашением

http://www.mathnet.ru/rus/agreement

Параметры загрузки:

IP : 54.237 .206 .68

26 апреля 2023 г., $05: 22: 46$ 


\section{Памяти Ивана Сергеевича Волкова, ректора Куйбышевского политехнического института}

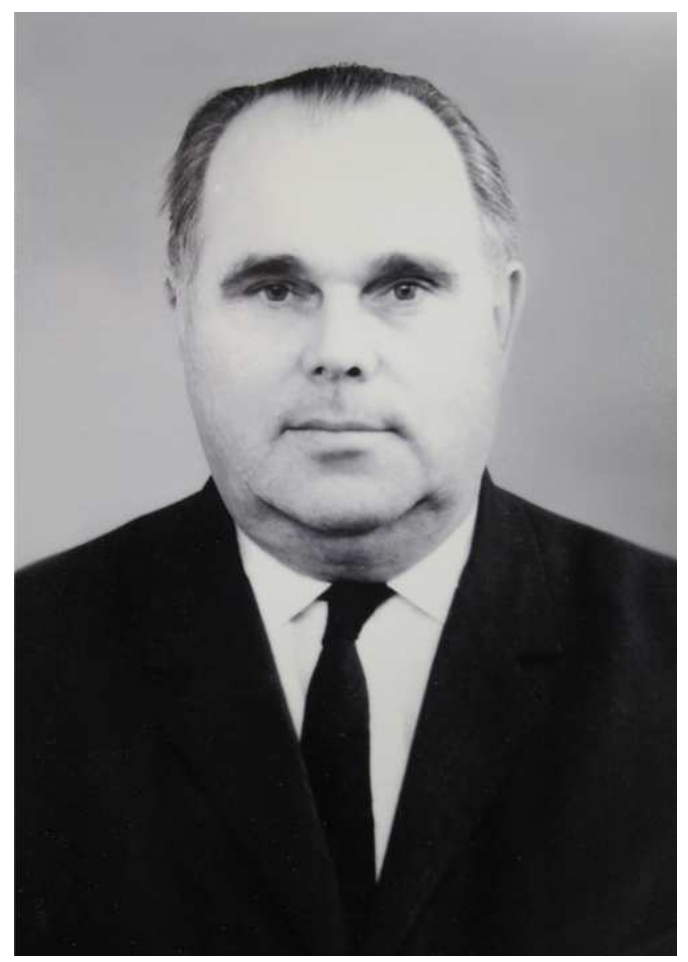

$(15.12 .1911-29.04 .1993)$

15 декабря 2011 года исполнилось 100 лет со дня рождения ректора Куйбышевского политехнического института им. В. В. Куйбышева (КПтИ), профессора, кандидата технических наук Ивана Сергеевича Волкова. Иван Сергеевич проработал в нашем вузе 43 года, он принимал непосредственное участие в создании факультета автоматики и измерительной техники (в настоящее время - факультет автоматики и информационных технологий), был организатором и руководителем двух кафедр, научно-исследовательских лабораторий. Иван Сергеевич приступил к исполнению обязанностей ректора КПтИ в июне 1968 года. Официально же приказ министра высшего и среднего специального образования (ВиССО) РСФСР В. Н. Столетова о назначении И. С. Волкова ректором института был издан 29 апреля 1969 года. Это было время, когда в политехническом на 9 факультетах ежегодно выпускалось в среднем 2500 инженеров. Более одной тысячи преподавателей, в числе которых - 400 докторов и кандидатов наук, проводили обучение студентов на дневном, вечернем и заочном отделениях по 31 специальности. В учебном процессе была задействована 61 кафедра, а число студентов достигало без 
малого 16 тысяч человек. Иван Сергеевич в течение 7 лет находился на посту ректора одного из крупнейших технических вузов Поволжского региона. За этот период наш институт выпустил 18238 инженеров, чьи знания нашли применение во всех отраслях экономики, и каждый из них не раз с благодарностью вспоминал alma mater.

Иван Сергеевич родился 2 декабря 1911 года (по ст. стилю) в поселке Никитовка Бахмутского уезда Харьковской губернии в семье железнодорожного служащего станции Никитовка Донецкой железной дороги Сергея Дмитриевича Волкова. Из автобиографии известно, что его отец 36 лет отработал на станции Никитовка путевым рабочим, переписчиком вагонов, весовщиком, багажным кассиром. Иван Сергеевич был третьим сыном, а всего в семье росло пятеро детей. В 1919 г. он лишился матери и в этом же году пошел учиться в Никитовскую школу-семилетку. Сразу после окончания школы Волков начал работу на шахте «Центральная» Щербиновского рудника в Донбассе в качестве ученика забойщика-крепильщика. Освоив профессию, он 3 года проработал на шахте крепильщиком. В сентябре 1929 года комсомолец Волков стал участником событий, которые происходили по всей полной трудового энтузиазма и преобразований советской стране. Его, как и многих других способных молодых людей рабоче-крестьянского происхождения, по рекомендации комитета ВЛКСМ и дополнительно по направлению «рудникового комитета» командировали в Москву для учебы на рабфаке с зачислением сразу на второй курс. Рабфак он окончил в числе слушателей ударной группы досрочно - в марте 1931 года. В том же месяце Иван Сергеевич стал студентом Московского электромашиностроительного института, позже преобразованного в электротехнический институт связи. В декабре 1935 года, тоже досрочно - на 6 месяцев раньше - Иван Сергеевич окончил факультет радио с квалификацией инженера широкого профиля по проектированию и эксплуатации установок радиосвязи. По распределению он был направлен в Горьковский (Нижегородский) электротехникум связи в качестве заведующего отделением радио и лабораторией, а также преподавателя специальных дисциплин. В октябре 1937 года в соответствии с решениями ЦК ВКП(б) и CHK СССР Иван Сергеевич Волков был направлен в Астрахань старшим инженером радиосвязи пароходства «Волготанкер». В феврале 1939 года в связи с семейными обстоятельствами он переехал в Куйбышев. Здесь он работал сначала старшим инженером в Куйбышевском областном управлении связи, затем преподавал в электротехникуме связи, одновременно занимая должность заместителя директора по учебной части. С началом Великой Отечественной войны техникум был закрыт, а Иван Сергеевич как специалист, имевший большой опыт в области радиосвязи, был переведен старшим инженером на радиостанцию РВ-16. С декабря 1941-го по март 1948 года он последовательно занимал должности главного инженера и начальника передающего радиоцентра Министерства связи СССР, а далее, с 1948-го до 1960 года, работал главным инженером, затем начальником дирекции радиосвязи и радиовещания. В июне 1946 года Указом Президиума Верховного Совета СССР за хорошую работу в период Великой Отечественной войны Иван Сергеевич Волков был награжден медалью «За доблестный труд», а в мае 1948 года ему был вручен знак «Почетный радист» за плодотворную работу в области радио. 
В 1949 году Иван Сергеевич начал преподавательскую деятельность в Куйбышевском индустриальном институте (КИИ), сначала с почасовой нагрузкой. С августа 1953 года он работал по совместительству старшим преподавателем кафедры общей и теоретической электротехники, а в 1954 году стал доцентом кафедры автоматических и электроизмерительных устройств. Иван Сергеевич был единственным преподавателем, который читал курсы промышленной электроники и телемеханики в нашем институте.

В своем интервью, посвященном 20-летию факультета автоматики и измерительной техники, идейный вдохновитель и основатель факультета, заслуженный деятель науки и техники РСФСР, профессор Лонгин Францевич Куликовский так вспоминал об этом времени: «В 1954 году на энергетическом факультете мною была создана кафедра автоматических, телемеханических и электроизмерительных устройств, которая размещалась в одном из корпусов на улице Вилоновской. Одновременно при кафедре была открыта аспирантура для подготовки кадров высшей квалификации... Под моим руководством готовили кандидатские диссертации О. И. Ульянов, А. Л. Цибер, К. Д. Колесников, отдавшие много сил становлению факультета, а также В. С. Семенов, М. Ф. Зарипов, И. С. Волков, позже ставший ректором института».

1 ноября 1959 года в соответствии с приказами министра ВиССО РСФСР В. Н. Столетова и директора КИИ В. С. Козлова был организован факультет автоматики и измерительной техники со специальностями 0606, 0626 и 0607. Созданный факультет в то время не имел аналогов ни в одном из вузов нашей страны. Соответственно специальностям появились такие кафедры, как «Автоматика и телемеханика», «Электроизмерительная техника», «Автоматизация производственных процессов». Кафедру автоматики и телемеханики возглавил Иван Сергеевич Волков, утвержденный в апреле 1959 года решением ВАK MBO CССР в ученом звании доцента по кафедре «Автоматические и измерительные устройства». Весной 1960 года, после избрания по конкурсу на должность заведующего кафедрой, Иван Сергеевич перешел на постоянную работу в КИИ. За короткий срок на кафедре были созданы современные лаборатории автоматического управления, электронных устройств в автоматике, телемеханики, следящих систем, позволившие осуществлять качественную подготовку инженеров и проводить научные исследования. В 1961 году при кафедре была создана отраслевая научно-исследовательская лаборатория средств автоматики и автоматизации производственных процессов, которая стала головной в области автоматизации кабельной промышленности, а её сотрудники успешно продолжают свою научную деятельность и в наши дни. В этом же году Ивану Сергеевичу была присуждена ученая степень кандидата технических наук. Являясь руководителем кафедры, Иван Сергеевич принимал непосредственное участие в разработке учебных программ, методических пособий, лекций и одновременно готовил учебный план для новой специальности 0547. В октябре 1963 года в КПтИ на инженерно-технологическом факультете под его руководством была организована кафедра приборных устройств для подготовки инженеров-радиомехаников. Позже специальность 0547 получила свое дальнейшее развитие как специальность 0575 с двумя специализациями, и в 1971 году Иван Сергеевич реорганизовал кафедру приборных устройств в кафедру радиотехнических устройств, где под его руководством были разработаны новые учебные программы, ме- 
тодические пособия, лекции по курсам: радиопередающие устройства, спецкурс CK-3, спецкурс CK-4, импульсная техника, были созданы новые учебные лаборатории. При новой кафедре была организована отраслевая научноисследовательская лаборатория радиоэлектроники и электронной техники.

С апреля 1963 по июнь 1968 года, до самого назначения его ректором, Иван Сергеевич занимал должность проректора по научной работе КПиИ. В этот период бурного развития промышленности в Поволжье политехническому институту необходимо было укреплять связь с производством. Создание на всех факультетах отраслевых научно-исследовательских лабораторий позволило увеличить объём научных исследований, в том числе и по заказам предприятий. Будучи проректором по научной работе, Волков уделял большое внимание организации новых научно-исследовательских лабораторий. К 1968 году в институте было создано 17 отраслевых научноисследовательских лабораторий, благодаря чему в 8 раз возрос объём хоздоговорных работ, повысилась эффективность научных исследований. Резко возросло число студентов, принимавших участие в научных исследованиях на кафедрах. Результатом активной научной деятельности студентов стало создание в 1970 году единого студенческого конструкторского бюро вуза. В 1973 году оно стало самостоятельным структурным подразделением КПтИ.

Научные разработки Ивана Сергеевича Волкова на кафедре радиотехнических устройств, которую он возглавлял до 1980 года, и руководимой им лаборатории радиоэлектроники также отличали высокий научный уровень и практическая направленность. Например, разработка вопросов ближней радиолокации и проектирование электронной техники проводились по специальным постановлениям правительства. Ученые кафедры ежегодно получали десятки авторских свидетельств на изобретения, были участниками различных научно-технических выставок и конференций, становились дипломантами и обладателями медалей ВДНХ СССР (ВВЦ). Иван Сергеевич имеет около 20 авторских свидетельств, технических усовершенствований и рационализаторских предложений. Он также был опытным методистом и высококвалифицированным преподавателем: основные его издания (а он опубликовал около 50 трудов) являются научно-методическими пособиями, это «Электронные устройства в автоматике», «Импульсные модуляторные устройства», «Автоматизация нагрева заготовок токами высокой частоты» и другие.

Кроме того, профессор (с 1972 года) Иван Сергеевич Волков многие годы входил в состав научно-методической комиссии по автоматике и телемеханике МВиССО СССР, был членом координационного совета Минвуза СССР и Министерства машиностроения СССР по специальностям 0547 и 0575 , на протяжении ряда лет входил в редколлегию научного журнала «Радиоэлектроника».

За многолетнюю плодотворную работу в высшей школе и развитие науки Иван Сергеевич был награжден правительственными наградами: орденом Трудового Красного Знамени, юбилейной медалью «За доблестный труд в ознаменование 100-летия со дня рождения В. И. Ленина». За вклад в развитие радио и безупречную работу в системе Министерства связи ему была вручена медаль «За трудовое отличие» и юбилейная бронзовая медаль имени А. С. Попова, учреждённая АН СССР. Иван Сергеевич проработал про- 
фессором на кафедре радиотехнических устройств с декабря 1980-го по август 1992 года.

29 апреля 1993 года он ушёл из жизни.

Открытые Иваном Сергеевичем специальности на двух факультетах и сегодня не потеряли своей актуальности. Кафедры «Автоматика и управление в технических системах» и «Радиотехнические устройства», которыми он руководил, по-прежнему являются профилирующими, имеют высокие рейтинги среди кафедр СамГТУ и вызывают большой интерес у абитуриентов.

В заключение следует вспомнить об одном важном для истории нашего вуза событии тех лет. При ректоре Иване Сергеевиче Волкове 29 октября 1968 года состоялась закладка мраморной плиты у первого учебного корпуса на ул. Первомайской и открытие 8 мая 1973 года монумента «Зачётная книжка и штык» студентам, преподавателям и сотрудникам, павшим в боях за Родину. С тех пор ежегодно накануне 9 Мая здесь собирается коллектив нашего университета и проходит митинг, посвящённый Победе в Великой Отечественной войне, с возложением цветов у монумента в память погибших героев.

А. А. Барсова, директор музейно-выставочного центра СамГТУ 